\title{
Editorial
}

\section{Uveal Melanoma}

\author{
Ulrich Pfeffer \\ IRCCS Ospedale Policlinico San Martino, 15132 Genova, Italy; ulrich.pfeffer@hsanmartino.it; \\ Tel.: +39-010-555-8462
}

Received: 3 December 2019; Accepted: 5 December 2019; Published: 10 December 2019

check for updates

Uveal melanoma (UM) is among the best characterized solid tumors. It has become clear that there are mainly two classes of uveal melanoma, which can be further subdivided into three or four subtypes that are clearly distinct by their histopathological, cytogenetic, and molecular characteristics. The analysis of the subtypes allows us to prognosticate the metastatic risk of each patient with an unmatched accuracy. While we essentially understand the molecular steps in uveal melanoma carcinogenesis, the mechanisms of metastasization and pronounced liver tropism are still poorly understood [1].

Unfortunately, the diagnostic and prognostic power is not matched by efficacy of therapy. The primary tumor is controlled by radiological and surgical interventions and local relapses are rare. Yet approximately half of the patients develop metastases that rapidly progress to the fatal stage. Despite research, survival of patients with metastatic uveal melanoma has not changed over decades. The identification of the most frequent putative driver mutations, which occur in a mutually exclusive manner in two genes encoding alpha subunits of $G$ proteins, namely $G$ protein subunit alpha $Q$ (GNAQ) and $G$ protein subunit alpha 11 (GNA11) [2,3], has indicated $G$ protein signaling and the activation of MAP kinases as potential targets, but MEK inhibitors have failed to show major effects in clinical trials [4]. More recently, the HIPPO-independent activation of the YAP/TAZ signaling pathway by mutated GNAQ and GNA11 has been described [5,6] but, at present, no specific inhibitors have been tested in the clinics. Recent reports on a specific inhibitor of the mutated form of GNAQ $[7,8]$ must be confirmed and translated into clinical applications. Immune checkpoint blockers that have met considerable success in the treatment of several cancers, including cutaneous melanoma [9], show very low response rates in uveal melanoma (but see [10-14]), likely due to the low number of neo-antigens, a consequence of a very low mutational burden [15-17].

Just like for other cancers, the identification of its Achilles' heel will rely on a deep understanding of the molecular and cellular features of the cancer cell in its permissive microenvironment. This will likely be possible by the thorough molecular characterization of ever more tumors, the development of better cellular and animal models, and the testing of new drugs, whether targeted at the molecular lesions typical of metastatic uveal melanoma or at the immune system.

In the present thematic issue, the authors of 44 articles (31 original research articles $[10,13,18-46]$, 11 reviews [4,11,12,14,47-53], one position paper [54], and one network report [55]) give insight into the current state of our understanding of uveal melanoma biology and clinics. They also discuss opportunities for the development of new therapeutics that will hopefully soon improve the survival rates of metastatic uveal melanoma patients.

The article collection comprises several reports that address basic biological features of uveal melanoma. Van der Kooij et al. review the differences between cutaneous and uveal melanomas, two tumors that share their origin [51]. Bakhoum and Esmaeli review what the analyses of The Cancer Genome Atlas (TCGA) uveal melanoma data have contributed to our understanding of the biology of this tumor [49]. Pfeffer et al. apply innovative data fusion techniques to the TCGA data in order to combine copy number alteration, DNA methylation and RNA expression datasets for the discovery of subtypes [20]. 
Piaggio et al. analyze a more extended cohort of 139 cases whose exomes have been sequenced and identify secondary somatic mutations delivering evidence that some of the apparently sporadic mutations that occur in very few or even single cases might contribute to tumor development [18]. Van Poppelen and coworkers analyze somatic mutations in the serine/arginine-rich splicing factor 2 gene (SRSF2) and show a mutational pattern that differs from that observed in myelodysplastic syndrome, where SRSF2 is frequently mutated, likely related to different sets of genes that show aberrant splicing [25].

Weis and coworkers present an epidemiological analysis indicating that the peri-ocular region might have a different or unique exposure pattern to ultraviolet radiation [43].

Pro-tumoral inflammation is addressed by Van Weeghel et al. who show that differences in the inflammatory phenotype and major histocompatibility complex (HLA) expression rely on chromosome 3 status but not on $G$ protein subunit alpha $Q$ (GNAQ) versus $G$ protein subunit alpha 11 (GNA11), mutations in uveal melanoma [27]. Souri and coworkers report that the nuclear factor kappa B (NFkB) pathway is associated with inflammation and HLA Class I expression in UM, and is upregulated when BRCA1 associated protein 1 (BAP1) expression is lost [31]. Souri et al. also show that HLA expression in uveal melanoma is both an indicator of malignancy and a potential target [47]. Wierenga et al. report on tumors in eyes that contain soluble HLA molecules in the aqueous humor that show features of more aggressive tumors and are related to reduced survival [24].

Piquet et al. address the role of hepatic stellate cells in creating a permissive niche for growth and therapy resistance of uveal melanoma metastases [34]. Brouwer et al. report on the association of the hypoxia-inducible factor 1 subunit alpha (HIF1 $\alpha$ ) and the von Hippel-Lindau protein (VHL) with BAP1 expression, inflammation, and tumor ischemia [36]. Consistent with this observation, Voropaev et al. show that knockdown of the hypoxia mediators cAMP response element-binding protein (CREB) or HIF1 $\alpha$ in UM cells by means of replication-competent retroviral vectors dramatically decreases UM tumor progression [32]. Brouwer et al. also address tumor angiogenesis and show that the monosomy 3 and the loss of BAP1 is associated with an increased microvascular density [37]. Van Beek et al. report on rare cases of regional lymphatic spread showing the recruitment of intratumoral lymphatics by uveal melanomas with extraocular extension from subconjunctival lymphatics [45]. Castet et al. review angiogenesis in uveal melanoma and discuss its importance [52].

Dogrusoz et al. show that the DNA-activated protein kinase PRKDC is overexpressed in high-risk uveal melanoma and that the inhibition of such kinases reduces the survival of the tumor cells [30]. Smit et al. identify microRNAs that are associated with uveal melanoma progression through the suppression of stability or translation of mRNAs coding for proteins of various cancer-related pathways [41].

Diagnostic procedures are addressed by Sun et al. who present an innovative artificial intelligence-based method to assess BAP1 expression by immunohistochemistry [19]. Le Guin et al. show that the specific GNAQ Q209R mutation is restricted to circumscribed choroidal hemangioma and very rare in uveal melanoma [46]. Matet and colleagues compare the cytogenetic profiles of choroidal melanoma samples retrieved before and after proton beam irradiation and demonstrate the higher reliability of endoresection material for cytogenetic analysis as compared to fine-needle aspiration biopsy [26]. Anand and coworkers report on a pilot study of circulating tumor cells (CTCs) in early-stage UM that predict an increased risk of metastatic disease [40]. Ferreira et al. provide a dedicated protocol for 3 Tesla magnetic resonance imaging for an improved diagnosis of uveal melanoma [44]. Frizziero et al. review the state of the art of uveal melanoma biopsies [48]. Mariani et al. propose a prognostic nomogram for patients with liver metastases of uveal melanoma to be applied to therapeutic decision-making and risk stratification [39]. Chau et al. propose a guideline for genetic screening of the familial BAP1 tumor predisposition syndrome [29].

Uveal melanoma therapy is addressed by several articles. Fiorentzis et al. propose electrochemotherapy for the treatment of uveal melanoma based on their experience in animal models [21]. Espensen and coworkers explore visual acuity deterioration and radiation-induced toxicity after brachytherapy [28]. 
Toutee et al. analyze the survival benefit and the risk of visual loss associated with early proton beam radiotherapy [33]. Jochems and colleagues report on treatment strategies and survival of metastatic uveal melanoma patients based on the Dutch Melanoma Treatment Registry [35]. Tura et al. provide data indicating that the therapeutic antibody ranibizumab, and not bevacizumab, suppresses metabolic activity, proliferation, and intracellular Vascular Endothelial Growth Factor A, VEGF-A, levels in uveal melanoma [38]. De Koning et al. report on synergistic effects of poly-ADP ribose polymerase inhibitors and chemotherapy that might rely on inhibition of YAP/TAZ signaling [42].

Immunotherapy, which has shown impressive effects in cutaneous melanoma but much less so in uveal melanoma, is in the focus of several contributions. Rossi and coworkers discuss the immunology of uveal melanoma in order to create a rationale for immunotherapy [11], and Schank and Hassel give an overview of immunotherapies for uveal melanoma [12]. Bol and coworkers present an interesting real-world perspective of therapy with immune checkpoint blockers in metastatic uveal melanoma that indicates some efficacy [13]. Fountain et al. show that immune checkpoint blockers might be useful in the adjuvant setting and call for clinical trials [10]. Damato et al. report on the promising T-cell receptor-gp100 fusion construct tebentafusp as a strategy for adaptive immunotherapy for metastatic uveal melanoma [14].

New targets for therapy are addressed by Rezzola et al. who describe the fibroblast growth factors (FGFs) and their receptors as potential therapy targets in uveal melanoma and show the efficacy of FGF traps [22]. Doherty et al. introduce the DNA-PK as a therapy target since its inhibition leads to increased non-homologous end joining and apoptosis [23]. Vivet-Noguer and colleagues review our knowledge of the molecular biology of uveal melanoma and how this might lead to the identification of new therapies [50]. Violanti et al. offer a different perspective on the molecular oncogenesis of uveal melanoma and the implications for therapy [53]. Croce et al. focus their review on targeted therapies that have not met with success in the clinics and try to give a perspective for future approaches to targeted therapy [4].

Rodrigues et al. provide a position paper of the UM Cure 2020 consortium [54] and Piperno-Neumann et al. report on how the EUropean Rare Adult solid CAncer Network (EURACAN) can be exploited for collaborations on uveal melanoma [55].

This collection of articles yields deep insight into uveal melanoma biology, indicating the routes of further research that will lead to a better understanding of tumor development and relevant, druggable pathways. Therapy of metastatic uveal melanoma remains of very limited efficacy; nonetheless, existing immunotherapy yields some responses. More specific interventions to instruct the immune system will hopefully yield major effects.

The scope of this thematic issue was to bring together experts in the field to sum up their experience and latest findings. Does uveal melanoma generally receive the necessary attention? The analysis of PubMed publications indicates that yes, it does (Figure 1). 


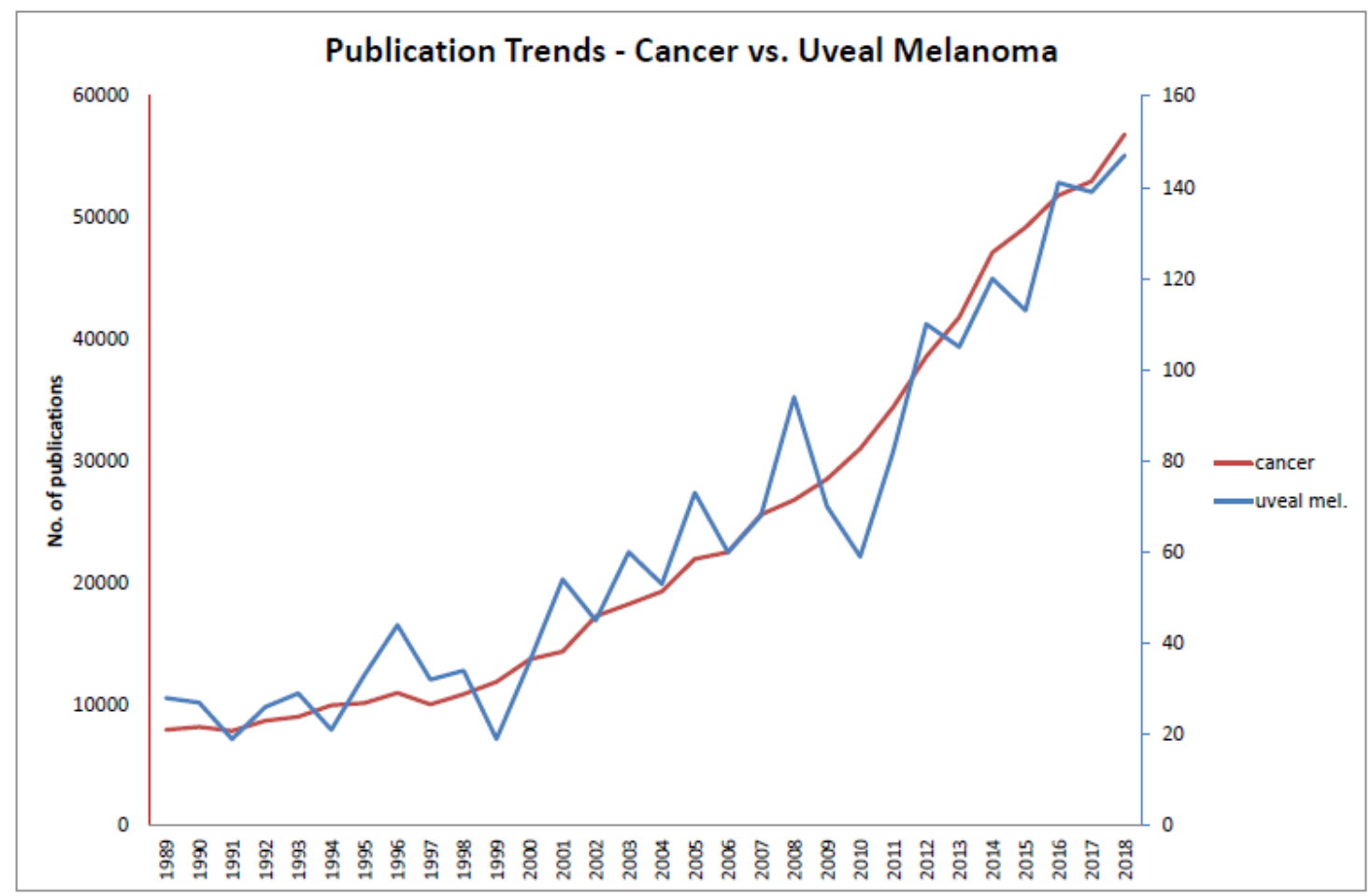

Figure 1. Publication trends. Numbers of publications listed in PubMed in the last 20 years are shown for the search terms "Cancer" (left $y$-axis) and "Uveal melanoma" (right $y$-axis).

The search terms "uveal melanoma" and "cancer" show similar publication dynamics. Interestingly, in 2015 1,633,390 new cases of cancers were registered in the United States (https://www.cdc.gov/cancer/ uscs/about/data-briefs/no3-USCS-highlights-2015-incidence.htm), 3360 of which were uveal melanomas (https://www.cancer.net/cancer-types/eye-cancer/statistics), a ratio of approximately 0.0021 that compares to the ratio of approximately 0.0023 of "uveal melanoma" over "cancer" publications. At present, the clinical trial database (https://clinicaltrials.gov/; interrogated on 18 November 2019) lists 71,324 clinical trials, 148 of which include uveal melanoma patients, a ratio of approximately 0.0021 .

While this is reassuring, the limited progress in uveal melanoma therapy remains alarming and, perhaps, much more attention should be dedicated to this rare but aggressive disease. The present thematic issue will certainly contribute to a better understanding of the peculiarities of uveal melanoma and, hopefully, will also help to make a much-needed step forward in its therapy.

Funding: This research was funded by the Associazione per la Ricerca sul Cancro, AIRC, grant number IG17103, and from the Compagnia di San Paolo (grant number 20067).

Acknowledgments: I thank Monica Fortin for secretarial help and Claudia Lo Sicco for project management.

Conflicts of Interest: The author declares that the present article also summarizes articles co-authored by him.

\section{References}

1. Amaro, A.; Gangemi, R.; Piaggio, F.; Angelini, G.; Barisione, G.; Ferrini, S.; Pfeffer, U. The biology of uveal melanoma. Cancer Metastasis Rev. 2017, 36, 109-140. [CrossRef] [PubMed]

2. Van Raamsdonk, C.D.; Bezrookove, V.; Green, G.; Bauer, J.; Gaugler, L.; O’Brien, J.M.; Simpson, E.M.; Barsh, G.S.; Bastian, B.C. Frequent somatic mutations of GNAQ in uveal melanoma and blue naevi. Nature 2009, 457, 599-602. [CrossRef] [PubMed]

3. Van Raamsdonk, C.D.; Griewank, K.G.; Crosby, M.B.; Garrido, M.C.; Vemula, S.; Wiesner, T.; Obenauf, A.C.; Wackernagel, W.; Green, G.; Bouvier, N.; et al. Mutations in GNA11 in uveal melanoma. N. Engl. J. Med. 2010, 363, 2191-2199. [CrossRef] [PubMed] 
4. Croce, M.; Ferrini, S.; Pfeffer, U.; Gangemi, R. Targeted Therapy of Uveal Melanoma: Recent Failures and New Perspectives. Cancers 2019, 11. [CrossRef] [PubMed]

5. Feng, X.; Degese, M.S.; Iglesias-Bartolome, R.; Vaque, J.P.; Molinolo, A.A.; Rodrigues, M.; Zaidi, M.R.; Ksander, B.R.; Merlino, G.; Sodhi, A.; et al. Hippo-independent activation of YAP by the GNAQ uveal melanoma oncogene through a trio-regulated rho GTPase signaling circuitry. Cancer Cell 2014, 25, 831-845. [CrossRef]

6. Yu, F.X.; Luo, J.; Mo, J.S.; Liu, G.; Kim, Y.C.; Meng, Z.; Zhao, L.; Peyman, G.; Ouyang, H.; Jiang, W.; et al. Mutant Gq/11 promote uveal melanoma tumorigenesis by activating YAP. Cancer Cell 2014, 25, 822-830. [CrossRef]

7. Schrage, R.; Schmitz, A.L.; Gaffal, E.; Annala, S.; Kehraus, S.; Wenzel, D.; Bullesbach, K.M.; Bald, T.; Inoue, A.; Shinjo, Y.; et al. The experimental power of FR900359 to study Gq-regulated biological processes. Nat. Commun. 2015, 6, 10156. [CrossRef]

8. Lapadula, D.; Farias, E.; Randolph, C.E.; Purwin, T.J.; McGrath, D.; Charpentier, T.H.; Zhang, L.; Wu, S.; Terai, M.; Sato, T.; et al. Effects of Oncogenic Galphaq and Galpha11 Inhibition by FR900359 in Uveal Melanoma. Mol. Cancer Res. 2019, 17, 963-973. [CrossRef]

9. Sharma, P.; Allison, J.P. The future of immune checkpoint therapy. Science 2015, 348, 56-61. [CrossRef]

10. Fountain, E.; Bassett, R.L.; Cain, S.; Posada, L.; Gombos, D.S.; Hwu, P.; Bedikian, A.; Patel, S.P. Adjuvant Ipilimumab in High-Risk Uveal Melanoma. Cancers 2019, 11. [CrossRef]

11. Rossi, E.; Schinzari, G.; Zizzari, I.G.; Maiorano, B.A.; Pagliara, M.M.; Sammarco, M.G.; Fiorentino, V.; Petrone, G.; Cassano, A.; Rindi, G.; et al. Immunological Backbone of Uveal Melanoma: Is There a Rationale for Immunotherapy? Cancers 2019, 11. [CrossRef] [PubMed]

12. Schank, T.E.; Hassel, J.C. Immunotherapies for the Treatment of Uveal Melanoma-History and Future. Cancers 2019, 11. [CrossRef] [PubMed]

13. Bol, K.F.; Ellebaek, E.; Hoejberg, L.; Bagger, M.M.; Larsen, M.S.; Klausen, T.W.; Kohler, U.H.; Schmidt, H.; Bastholt, L.; Kiilgaard, J.F.; et al. Real-World Impact of Immune Checkpoint Inhibitors in Metastatic Uveal Melanoma. Cancers 2019, 11. [CrossRef] [PubMed]

14. Damato, B.E.; Dukes, J.; Goodall, H.; Carvajal, R.D. Tebentafusp: T Cell Redirection for the Treatment of Metastatic Uveal Melanoma. Cancers 2019, 11. [CrossRef] [PubMed]

15. Robertson, A.G.; Shih, J.; Yau, C.; Gibb, E.A.; Oba, J.; Mungall, K.L.; Hess, J.M.; Uzunangelov, V.; Walter, V.; Danilova, L.; et al. Integrative Analysis Identifies Four Molecular and Clinical Subsets in Uveal Melanoma. Cancer Cell 2018, 33, 151. [CrossRef]

16. Field, M.G.; Durante, M.A.; Anbunathan, H.; Cai, L.Z.; Decatur, C.L.; Bowcock, A.M.; Kurtenbach, S.; Harbour, J.W. Punctuated evolution of canonical genomic aberrations in uveal melanoma. Nat. Commun. 2018, 9, 116. [CrossRef]

17. Martin, M.; Masshofer, L.; Temming, P.; Rahmann, S.; Metz, C.; Bornfeld, N.; van de Nes, J.; Klein-Hitpass, L.; Hinnebusch, A.G.; Horsthemke, B.; et al. Exome sequencing identifies recurrent somatic mutations in EIF1AX and SF3B1 in uveal melanoma with disomy 3. Nat. Genet. 2013, 45, 933-936. [CrossRef]

18. Piaggio, F.; Tozzo, V.; Bernardi, C.; Croce, M.; Puzone, R.; Viaggi, S.; Patrone, S.; Barla, A.; Coviello, D.; Jager, M.J.; et al. Secondary Somatic Mutations in G-Protein-Related Pathways and Mutation Signatures in Uveal Melanoma. Cancers 2019, 11. [CrossRef]

19. Sun, M.; Zhou, W.; Qi, X.; Zhang, G.; Girnita, L.; Seregard, S.; Grossniklaus, H.E.; Yao, Z.; Zhou, X.; Stalhammar, G. Prediction of BAP1 Expression in Uveal Melanoma Using Densely-Connected Deep Classification Networks. Cancers 2019, 11. [CrossRef]

20. Pfeffer, M.; Uschmajew, A.; Amaro, A.; Pfeffer, U. Data Fusion Techniques for the Integration of Multi-Domain Genomic Data from Uveal Melanoma. Cancers 2019, 11. [CrossRef]

21. Fiorentzis, M.; Viestenz, A.; Siebolts, U.; Seitz, B.; Coupland, S.E.; Heinzelmann, J. The Potential Use of Electrochemotherapy in the Treatment of Uveal Melanoma: In Vitro Results in 3D Tumor Cultures and In Vivo Results in a Chick Embryo Model. Cancers 2019, 11. [CrossRef] [PubMed]

22. Rezzola, S.; Ronca, R.; Loda, A.; Nawaz, M.I.; Tobia, C.; Paganini, G.; Maccarinelli, F.; Giacomini, A.; Semeraro, F.; Mor, M.; et al. The Autocrine FGF/FGFR System in both Skin and Uveal Melanoma: FGF Trapping as a Possible Therapeutic Approach. Cancers 2019, 11. [CrossRef] [PubMed] 
23. Doherty, R.E.; Bryant, H.E.; Valluru, M.K.; Rennie, I.G.; Sisley, K. Increased Non-Homologous End Joining Makes DNA-PK a Promising Target for Therapeutic Intervention in Uveal Melanoma. Cancers 2019, 11. [CrossRef] [PubMed]

24. Wierenga, A.P.A.; Gezgin, G.; van Beelen, E.; Eikmans, M.; Spruyt-Gerritse, M.; Brouwer, N.J.; Versluis, M.; Verdijk, R.M.; van Duinen, S.G.; Marinkovic, M.; et al. Soluble HLA in the Aqueous Humour of Uveal Melanoma Is Associated with Unfavourable Tumour Characteristics. Cancers 2019, 11. [CrossRef] [PubMed]

25. Van Poppelen, N.M.; Drabarek, W.; Smit, K.N.; Vaarwater, J.; Brands, T.; Paridaens, D.; Kilic, E.; de Klein, A. SRSF2 Mutations in Uveal Melanoma: A Preference for In-Frame Deletions? Cancers 2019, 11. [CrossRef]

26. Matet, A.; Ait Rais, K.; Malaise, D.; Angi, M.; Dendale, R.; Tick, S.; Lumbroso-Le Rouic, L.; Levy-Gabriel, C.; Rodrigues, M.; Pierron, G.; et al. Comparative Cytogenetic Abnormalities in Paired Choroidal Melanoma Samples Obtained Before and After Proton Beam Irradiation by Transscleral Fine-Needle Aspiration Biopsy and Endoresection. Cancers 2019, 11. [CrossRef]

27. Van Weeghel, C.; Wierenga, A.P.A.; Versluis, M.; van Hall, T.; van der Velden, P.A.; Kroes, W.G.M.; Pfeffer, U.; Luyten, G.P.M.; Jager, M.J. Do GNAQ and GNA11 Differentially Affect Inflammation and HLA Expression in Uveal Melanoma? Cancers 2019, 11. [CrossRef]

28. Espensen, C.A.; Appelt, A.L.; Fog, L.S.; Gothelf, A.B.; Thariat, J.; Kiilgaard, J.F. Predicting Visual Acuity Deterioration and Radiation-Induced Toxicities after Brachytherapy for Choroidal Melanomas. Cancers 2019, 11. [CrossRef]

29. Chau, C.; van Doorn, R.; van Poppelen, N.M.; van der Stoep, N.; Mensenkamp, A.R.; Sijmons, R.H.; van Paassen, B.W.; van den Ouweland, A.M.W.; Naus, N.C.; van der Hout, A.H.; et al. Families with BAP1-Tumor Predisposition Syndrome in The Netherlands: Path to Identification and a Proposal for Genetic Screening Guidelines. Cancers 2019, 11. [CrossRef]

30. Dogrusoz, M.; Ruschel Trasel, A.; Cao, J.; olak, S.; van Pelt, S.I.; Kroes, W.G.M.; Teunisse, A.; Alsafadi, S.; van Duinen, S.G.; Luyten, G.P.M.; et al. Differential Expression of DNA Repair Genes in Prognostically-Favorable versus Unfavorable Uveal Melanoma. Cancers 2019, 11. [CrossRef]

31. Souri, Z.; Wierenga, A.P.A.; van Weeghel, C.; van der Velden, P.A.; Kroes, W.G.M.; Luyten, G.P.M.; van der Burg, S.H.; Jochemsen, A.G.; Jager, M.J. Loss of BAP1 Is Associated with Upregulation of the NFkB Pathway and Increased HLA Class I Expression in Uveal Melanoma. Cancers 2019, 11. [CrossRef] [PubMed]

32. Voropaev, H.; Gimmelshein Vatkin, M.; Shneor, D.; Luski, S.; Honigman, A.; Frenkel, S. Infectious Knockdown of CREB and HIF-1 for the Treatment of Metastatic Uveal Melanoma. Cancers 2019, 11. [CrossRef] [PubMed]

33. Toutee, A.; Angi, M.; Dureau, S.; Levy-Gabriel, C.; Rouic, L.L.; Dendale, R.; Desjardins, L.; Cassoux, N. Long-Term Visual Outcomes for Small Uveal Melanoma Staged T1 Treated by Proton Beam Radiotherapy. Cancers 2019, 11. [CrossRef] [PubMed]

34. Piquet, L.; Dewit, L.; Schoonjans, N.; Millet, M.; Berube, J.; Gerges, P.R.A.; Bordeleau, F.; Landreville, S. Synergic Interactions Between Hepatic Stellate Cells and Uveal Melanoma in Metastatic Growth. Cancers 2019, 11. [CrossRef]

35. Jochems, A.; van der Kooij, M.K.; Fiocco, M.; Schouwenburg, M.G.; Aarts, M.J.; van Akkooi, A.C.; van den Berkmortel, F.; Blank, C.U.; van den Eertwegh, A.J.M.; Franken, M.G.; et al. Metastatic Uveal Melanoma: Treatment Strategies and Survival-Results from the Dutch Melanoma Treatment Registry. Cancers 2019, 11. [CrossRef]

36. Brouwer, N.J.; Wierenga, A.P.A.; Gezgin, G.; Marinkovic, M.; Luyten, G.P.M.; Kroes, W.G.M.; Versluis, M.; van der Velden, P.A.; Verdijk, R.M.; Jager, M.J. Ischemia Is Related to Tumour Genetics in Uveal Melanoma. Cancers 2019, 11. [CrossRef]

37. Brouwer, N.J.; Gezgin, G.; Wierenga, A.P.A.; Bronkhorst, I.H.G.; Marinkovic, M.; Luyten, G.P.M.; Versluis, M.; Kroes, W.G.M.; van der Velden, P.A.; Verdijk, R.M.; et al. Tumour Angiogenesis in Uveal Melanoma Is Related to Genetic Evolution. Cancers 2019, 11. [CrossRef]

38. Tura, A.; Pawlik, V.E.; Rudolf, M.; Ernesti, J.S.; Stutzer, J.N.; Grisanti, S.; Ranjbar, M. Uptake of Ranibizumab but Not Bevacizumab into Uveal Melanoma Cells Correlates with a Sustained Decline in VEGF-A Levels and Metastatic Activities. Cancers 2019, 11. [CrossRef]

39. Mariani, P.; Dureau, S.; Savignoni, A.; Rouic, L.L.; Levy-Gabriel, C.; Piperno-Neumann, S.; Rodrigues, M.J.; Desjardins, L.; Cassoux, N.; Servois, V. Development of a Prognostic Nomogram for Liver Metastasis of Uveal Melanoma Patients Selected by Liver MRI. Cancers 2019, 11. [CrossRef] 
40. Anand, K.; Roszik, J.; Gombos, D.; Upshaw, J.; Sarli, V.; Meas, S.; Lucci, A.; Hall, C.; Patel, S. Pilot Study of Circulating Tumor Cells in Early-Stage and Metastatic Uveal Melanoma. Cancers 2019, 11. [CrossRef]

41. Smit, K.N.; Chang, J.; Derks, K.; Vaarwater, J.; Brands, T.; Verdijk, R.M.; Wiemer, E.A.C.; Mensink, H.W.; Pothof, J.; de Klein, A.; et al. Aberrant MicroRNA Expression and Its Implications for Uveal Melanoma Metastasis. Cancers 2019, 11. [CrossRef]

42. De Koning, L.; Decaudin, D.; El Botty, R.; Nicolas, A.; Carita, G.; Schuller, M.; Ouine, B.; Cartier, A.; Naguez, A.; Fleury, J.; et al. PARP Inhibition Increases the Response to Chemotherapy in Uveal Melanoma. Cancers 2019, 11. [CrossRef] [PubMed]

43. Weis, E.; Vrouwe, S.Q.; LeBaron, D.B.; Parliament, M.B.; Shields, J.; Shields, C.L. Changes in Ultraviolet Radiation Exposure to the Ocular Region: A Population-Based Study. Cancers 2019, 11. [CrossRef] [PubMed]

44. Ferreira, T.A.; Grech Fonk, L.; Jaarsma-Coes, M.G.; van Haren, G.G.R.; Marinkovic, M.; Beenakker, J.M. MRI of Uveal Melanoma. Cancers 2019, 11. [CrossRef] [PubMed]

45. Van Beek, J.G.M.; van den Bosch, Q.C.C.; Naus, N.; Paridaens, D.; de Klein, A.; Kilic, E.; Verdijk, R.M. Absence of Intraocular Lymphatic Vessels in Uveal Melanomas with Extrascleral Growth. Cancers 2019, 11. [CrossRef] [PubMed]

46. Le Guin, C.H.D.; Metz, K.A.; Kreis, S.H.; Bechrakis, N.E.; Bornfeld, N.; Zeschnigk, M.; Lohmann, D.R. GNAQ Q209R Mutations Are Highly Specific for Circumscribed Choroidal Hemangioma. Cancers 2019, 11. [CrossRef]

47. Souri, Z.; Wierenga, A.P.A.; Mulder, A.; Jochemsen, A.G.; Jager, M.J. HLA Expression in Uveal Melanoma: An Indicator of Malignancy and a Modifiable Immunological Target. Cancers 2019, 11. [CrossRef]

48. Frizziero, L.; Midena, E.; Trainiti, S.; Londei, D.; Bonaldi, L.; Bini, S.; Parrozzani, R. Uveal Melanoma Biopsy: A Review. Cancers 2019, 11. [CrossRef]

49. Bakhoum, M.F.; Esmaeli, B. Molecular Characteristics of Uveal Melanoma: Insights from the Cancer Genome Atlas (TCGA) Project. Cancers 2019, 11. [CrossRef]

50. Vivet-Noguer, R.; Tarin, M.; Roman-Roman, S.; Alsafadi, S. Emerging Therapeutic Opportunities Based on Current Knowledge of Uveal Melanoma Biology. Cancers 2019, 11. [CrossRef]

51. Van der Kooij, M.K.; Speetjens, F.M.; van der Burg, S.H.; Kapiteijn, E. Uveal Versus Cutaneous Melanoma; Same Origin, Very Distinct Tumor Types. Cancers 2019, 11. [CrossRef] [PubMed]

52. Castet, F.; Garcia-Mulero, S.; Sanz-Pamplona, R.; Cuellar, A.; Casanovas, O.; Caminal, J.M.; Piulats, J.M. Uveal Melanoma, Angiogenesis and Immunotherapy, Is There Any Hope? Cancers 2019, 11. [CrossRef] [PubMed]

53. Violanti, S.S.; Bononi, I.; Gallenga, C.E.; Martini, F.; Tognon, M.; Perri, P. New Insights into Molecular Oncogenesis and Therapy of Uveal Melanoma. Cancers 2019, 11. [CrossRef] [PubMed]

54. Rodrigues, M.; Koning, L.; Coupland, S.E.; Jochemsen, A.G.; Marais, R.; Stern, M.H.; Valente, A.; Barnhill, R.; Cassoux, N.; Evans, A.; et al. So Close, yet so Far: Discrepancies between Uveal and Other Melanomas. A Position Paper from UM Cure 2020. Cancers 2019, 11. [CrossRef] [PubMed]

55. Piperno-Neumann, S.; Piulats, J.M.; Goebeler, M.; Galloway, I.; Lugowska, I.; Becker, J.C.; Vihinen, P.; Van Calster, J.; Hadjistilianou, T.; Proenca, R.; et al. Uveal Melanoma: A European Network to Face the Many Challenges of a Rare Cancer. Cancers 2019, 11. [CrossRef]

(C) 2019 by the author. Licensee MDPI, Basel, Switzerland. This article is an open access article distributed under the terms and conditions of the Creative Commons Attribution (CC BY) license (http://creativecommons.org/licenses/by/4.0/). 